\title{
The Physician in Ancient Israel: His Status and Function
}

\author{
NIGEL ALLAN*
}

For centuries the Jews have distinguished themselves in the practice of medicine, a tradition reaching back to Talmudic times when rabbis were frequently acknowledged for their healing skills. ${ }^{1}$ This trend developed during the medieval period in Europe, when Jews, excluded from practically all the learned professions, turned to medicine as a means of livelihood. ${ }^{2}$ As a result, the Jews have been esteemed for their medical skills and, in our own time, continue to occupy a distinguished position in the medical profession throughout the world. ${ }^{3}$ Yet the honoured place occupied by the physician in Jewish society was not inherent to ancient Israel, but evolved through the centuries in ever changing circumstances.

This article traces the development of the role of the physician in ancient Israel down to the close of the second Temple period in AD 70. It draws upon biblical pseudepigraphal and apocryphal literature, also referring to other sources when relevant to the subject (e.g. Josephus, Philo, the Talmud, etc.). The linguistic aspects of the root $r f$ ' in the Hebrew Scriptures are examined before the paper moves into the post-exilic period in which the development of the concept of the professional healer is traced down to the first description of the physician in Jewish literature by Shim'on b. Jeshua' b. Sira, known in Christian and Greek literature as Jesus ben Sirach, during the second century BC.

In biblical times sickness and death were interpreted as God's punishment for disobedience to his will. Yet although punishment was in the hand of God so was healing if the subject was contrite. This is made clear following God's deliverance of Israel from

\section{* Nigel Allan, PhD, ALA, Curator of Oriental Manuscripts and Printed Books, Wellcome Library for the History and Understanding of Medicine, 183 Euston Road, London NW1 2BE. \\ I am indebted to my colleague, Dr Nikolaj Serikoff for reading this paper and making several helpful suggestions.}

\footnotetext{
${ }^{1}$ Since it was not considered appropriate to receive payment from the study or teaching of the Scriptures (Pirke Aboth 4:7) the practice of medicine often provided the rabbi with an income. Many Talmudic sages were accomplished physicians, e.g. R Hanina ben Dosa (first century) or R Ishmael ben Elisha (second century). See F Rosner, Medicine in the Bible and the Talmud:
}

selections from classical Jewish sources, Hoboken, NJ, KTAV Publishing House, and New York, Yeshiva University Press, 1995, p. 15.

${ }^{2}$ It was during this period that many Jewish physicians were engaged in the translation and transmission to the west of the corpus of classical Greek medicine preserved and augmented by the Arabs. See S W Baron, $A$ social and religious history of the Jews, vol. 4, Meeting of east and west, New York and London, Columbia University Press, 1957-67, pp. 3, 32-3.

${ }^{3} \mathrm{C}$ Roth, The Jewish contribution to civilisation, London, Macmillan, 1938, pp. 191-216, and H Cohen and I Carmin (eds), Jews in the world of science: a biographical dictionary of Jews eminent in the natural and social sciences, New York, Monde, 1956. 


\section{Nigel Allan}

captivity in Egypt, in that Israel would not be visited with the diseases inflicted on Egypt providing God's commandments were obeyed, "I am the Lord your healer" (Exodus 15:26). ${ }^{4}$ To be well, which included health in its broadest sense, was expressed by the term shalom, whose root denotes "completion", "fulfilment", "wholeness" and a "restored relationship with God". Since sickness, regarded as the result of sin, cut the believer off from God, the patient was considered ritually unclean and in a state of unholiness. Isaiah described his sin as uncleanness of lips, teme' sefatayim (Isaiah 6: 5), the same root $t m^{\prime}$ ' in the intensive form (piel) being used to describe the "leper" pronounced unclean by the priest (Leviticus 13:3). In the course of the ritual cleansing of the "leper", two birds were offered in sacrifice, one of which was killed and the other dipped in its blood, with which the patient was also sprinkled. Following this ritual procedure, the surviving bird was set free, so removing, apparently by magical means, the pathogenic agent (Leviticus 14:1-9). ${ }^{6}$ Many incidents preserved in the Hebrew Scriptures bear witness to the prevalence of magic in ancient Israel ${ }^{7}$ in spite of frequent pronouncements against it. ${ }^{8}$ These signify its pervasiveness, of which, in some instances as here, the devotee may have been unaware.

The priest's duty was to preserve holiness and to prevent contamination of the cult by any encroachment on its sanctity. ${ }^{9}$ Out of 613 biblical commandments, 213 are related to health or matters of hygiene,$^{10}$ which indicates the uniqueness of the Hebrews among ancient peoples in their regulations to ensure social hygiene essential for the health of the community. Yet in none of these regulations is there any evidence to suggest that the priest had a healing role, although some medical knowledge can be assumed to identify the symptoms of disease. The

\footnotetext{
${ }^{4}$ Cf. Deut. 32:39, "I kill and I make alive, I wound and I heal". For the relationship between sickness and sin, see Num. 12:9-13; Deut. 28:15, 21, 22; 1 Kings 14:1-18; Ps 38:3-9; 2 Chron. 21:6, 19.

${ }^{5}$ See Gesenius's Hebrew and Chaldee lexicon to the Old Testament Scriptures, transl. S P Tregelles, London, Samuel Bagster, 1859, pp. 829-30; L Koehler and W Baumgartner, Hebräisches und aramäisches Lexikon zum Alten Testament, Leiden, E J Brill, 1990, pp. 1418-25.

${ }^{6}$ According to the ritual described in Lev. 14: $1-32$, one bird was slaughtered over a bowl of fresh water and its blood sprinkled on the patient. The living bird, with cedar wood, scarlet thread and hyssop, was dipped in its blood. Following this procedure, the patient was permitted to enter the camp but had to remain outside his tent until further cultic procedures were carried out to ensure there was no risk of ritual or physical contamination to those around him. Then only was the patient considered ritually cleansed and restored to the cultic community. See Matt. 8:2-4; Mark 1:40-44; Luke $5: 12-15$, where Jesus charged the "leper" he had healed to show himself to the priest and to make a sacrifice according to the Mosaic law. For
}

similar rituals in other Near Eastern cultures, see W G Lambert, 'A middle Assyrian medical text', IRAQ, 1969, 31: 28-39.

${ }^{7}$ For example, the consultation by Ahaziah, king of Israel, of the oracle of the God, Baalzebub of Ekron (2 Kings 1:2-17), known from Ugarit texts to be invoked to drive out the demon of disease. See M Dietrich and $O$ Loretz, 'Die Ba'al-titel b'l ars und aliy qrdm', UgaritForschungen, 1980, 12: 391-3, p. 392, and idem, 'Ugaritische Rituale nebst einem Opfertext aus Mari', in O Kaiser (ed.), Text aus der Umwelt des Alten Testaments, Gütersloh, Gütersloher

Verlaghaus Mohn, 1988, vol. 2, pp. 339-42. Cf. Hos. 13:14; Ps 91:5-6; Job 18:10ff.

${ }^{8}$ Cf. Exod. 22:17 (v. 18 E.V.); Lev. 20:6, 27; Deut. 18:9-14; Isa. 47:9, 12; Jer. 27:9, and the difficult passage in Ezek. 13:17-23.

${ }^{9}$ Biblical leprosy (Lev. 13), secretions of bodily fluids (Lev. 15), physical defects (Lev. 21: 16-24) were unacceptable to the cult that served the Lord who had "purer eyes than to behold evil and canst not look on iniquity" (Hab. 1:13).

${ }^{10}$ See Rosner, op. cit., note 1 above, p. 9. These were implemented as part of Israel's cultic practice. 


\section{The Physician in Ancient Israel}

function of the priest was to ensure the holiness of the cult which necessitated the absolute purity of its devotees from all contagion and other defects that made them unworthy to participate in the worship of God. In the discharge of this duty, the office of the priest therefore included the protection of the community from infectious disease. ${ }^{11}$ Similarly, the prophets also possessed some knowledge of medicine, as witnessed in the treatment by Elijah of the apparently dead son of the widow of Zarephath (1 Kings 17:17-23). On the restoration of her son, the widow acknowledged the prophet as a man of God in whose mouth "the word of the Lord is truth" (v. 24). ${ }^{12}$ Whether these miracles were the result of natural phenomena or not, they were carried out by God's agents, the prophets, whose function was to act on the Lord's behalf. Nowhere, however, is the prophet described as a healer, rofe'. This function was reserved exclusively to God who alone discharged his healing.

The root $r f^{\prime}$ is the most frequently used in the Hebrew Scriptures to denote healing and occurs in various forms some sixty-six times, in half of which it has a metaphorical meaning and in almost a third is used to describe physical healing. ${ }^{13}$ The root is cognate to similar Semitic roots meaning to sew together or to mend, possibly with an onomatopoeic basis derived from the sound of a person sewing rapidly. ${ }^{14}$ Hence in the sense of healing a wound by sewing the edges of the flesh together as in Job $5: 18 .{ }^{15}$ The root is also used in a secular sense unrelated to physical or spiritual healing as in the description of Elijah restoring the altar of the Lord (1 Kings 18: 30). ${ }^{16}$ The basic idea, therefore, of the root $r f^{\prime}$ is to restore the object to its original condition and in human terms to undo the disruption caused by sin and restore the sinner to the correct relationship with God.

The practice of medicine was justified in Talmudic times on the basis of Exodus

\footnotetext{
${ }^{11}$ See J Preuss, Biblisch-talmudische Medizin: Beiträge zur Geschichte der Heilkunde und der Kultur überhaupt, Berlin, S Karger, 1911, p. 18. The Hebrews were aware that contagious diseases were spread by direct contact as well as by clothing, household utensils and other items related to everyday life. For example, all clothing of soldiers returning from battle and their equipment had to be disinfected by fire or washing in boiling water (Num. 31:21-24).

${ }^{12}$ For a full discussion of what appears to have been mouth to mouth resuscitation see, e.g. Rosner, op. cit., note 1 above, pp. 66ff. Similarly, the Syrian commander, Naaman, sought and received a cure for his "leprosy" through Elisha. As a result, Naaman declared that there was "not a God in all the earth, but in Israel" ( 2 Kings 5: $1-15)$. For the healing activities of Isaiah, see 2 Kings 20:7; Isa. 38:21. H Avalos in Illness and health care in the Ancient Near East: the role of the temple in Greece, Mesopotamia, and Israel, Harvard Semitic Museum Monographs, No. 54, Atlanta, GA, Scholars Press, 1995, suggests on pp. 298-9 that the decline of the prophet may have eventually paved the way for the healing
}

status of the physician to be legitimized in the second Temple period.

${ }^{13}$ See Klaus Seybold, Das Gebet des Kranken im Alten Testament: Untersuchungen zur Bestimmung und Zuordnung der Krankheits- und Heilungspsalmen, Stuttgart, W Kohlhammer, 1973 , p. 28, where he gives a detailed analysis of the root $r f^{\prime}$.

${ }^{14}$ For example, rafa' $a$ in Arabic and raf' $a$ in Ethiopic. See Gesenius's Hebrew and Chaldee lexicon, op. cit, note 5 above, pp. 775-6; Koehler and Baumgartner, op. cit., note 5 above, pp. $1186 \mathrm{ff}$.

15 "For although he maketh sore and bindeth up: he woundeth and his hands make whole", veyadav tirpenah, the predicate $r f^{\prime}$ being used in parallel to $h b s h$ "to bind up". See also Isa. 19:22; 30:26; Eccles. 3:3.

${ }^{16}$ In a similar sense when Jeremiah declares that the Lord will shatter the nation as an earthen vessel is shattered so that it cannot be mended (Jer. 19:11). The word $r f^{\prime}$ in this context means to bring the earthen vessel back to the state in which it was before it was broken. 
$21: 19^{17}$ in which it is stipulated that in the event of a quarrel leading to physical confrontation between two men in which one is injured, there is no liability on the other except he is "to pay for the loss of his time, and shall cause him to be thoroughly healed", shivto yiten ve-rapo' yerape. The rendering "to cause him to be thoroughly healed" gives rise to the assumption that a physician was available who would be employed, probably for payment, to render the victim fit. ${ }^{18}$ This, however, does not appear to be the translation of the Hebrew as it stands in the Masoretic text. When the victim has presumably recovered sufficiently to rise from his bed and walk with the aid of a stick, the perpetrator of the injury will be deemed innocent, but will give the victim his shevet, i.e. the loss incurred during his enforced inactivity (see vv. 18b, 19a), and thus he will restore him to the position he enjoyed before his injury. Rather than being provided with healing, which was exclusive to God, the victim was restored by way of compensation to the material position he held before the conflict ${ }^{19}$ and this restoration is subsequent to his rising from his bed and being able to take advantage of the compensation offered. The difficulty of this passage was recognized in the Greek translation of the Septuagint, as we shall see later.

The root $r f^{\prime}$ is used in the active participle in a number of instances in the Hebrew Scriptures and translated as one who discharges healing, i.e. a physician. We meet the predicate in this form in Genesis 50:2 where the death of Jacob in Egypt is recorded. Joseph ordered his embalming in preparation for the removal of his father's remains for burial in Israel and this process was carried out by rof' $i m$, rendered in the English translations as "physicians". Clearly the term denotes those proficient in embalming, ${ }^{20}$ a highly specialized procedure in ancient Egypt. ${ }^{21}$ Here the term rof' im is used in its basic meaning "to mend, to sew together", i.e. to restore a body to its best condition in preparation for burial. As this was a custom alien to Israel, there was no precise term available to the writer to designate those who carried out this procedure, so the Hebrew term that best described this process was employed. ${ }^{22}$ The prophet Jeremiah, in lamenting the absence of the Lord, puts the rhetorical question in the mouth of God's people-"Is the Lord not in Zion, is her king no longer there" (Jeremiah 8:19), making the comparison with the balm in Gilead where there is no physician - "is there no balm in Gilead, ${ }^{23}$ no physician there" (v. 22). The

\footnotetext{
${ }^{17}$ It was taught in the school of Ishmael that this verse provided divine authorization for the practice of medicine, an interpretation found in the Talmud. See b Berakhot 60a.

${ }^{18}$ See S S Kottek, Medicine and hygiene in the works of Flavius Josephus, Leiden, E J Brill, 1994, p. 11.

${ }^{19}$ Which, in an agricultural society, could be reparation of crops not gathered in if the injury took place at harvest time or some other related compensation.

${ }^{20}$ The Septuagint translates with the term

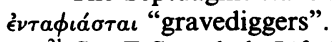

${ }^{21}$ See E Strouhal, Life in ancient Egypt, Cambridge University Press, 1992, pp. 257-64.

${ }^{22}$ A point made by Preuss, op. cit., note 11 above, p. 18. M von Nordheim, 'Ich bin der Herr, dein Arzt': der Arzt in der Kultur des alten Israel?,
}

Würzburger medizinhistorische Forschungen, vol. 63, Würzburg, Königshausen \& Neumann, 1998, p. 14 , translates the word hathanutim (v. 3) to designate "the embalmers". It is however a passive participle and correctly translated in the New English Bible as "which was the time for embalming".

${ }^{23}$ Y Feliks, 'Balm of Gilead and myrrh', Koroth, 1982, 8: 189-92, identifies tsori, translated "balm", with balsam which grows around Jericho, see Jer. 46:11. Josephus states that Antonius presented Cleopatra with orchards of palms and balsam trees near Jericho, Flavius Josephus, The Jewish war, Bk 1: 361 (Josephus, The Jewish war, Bks 1-3, vol. 2, transl. H St J Thackeray, Loeb Classical Library, London, W Heinemann; New York, G P Putnam's, 1927, pp. 168-9). 


\section{The Physician in Ancient Israel}

active participle of $r f$ ' translated by "physician" is more appropriately rendered "is there no balm in Gilead, is there no healing there". A further reference to $r f^{\prime}$ ' in the active participle is found in Job 13:4 where the term rof'e 'elil kulekem is rendered "physicians of no account" in describing the advice given Job by one of his comforters. ${ }^{24}$ In the first half of the verse we read tofle sheqer "sewers together of lies", and therefore the appropriate sense of rof'e in the second half of the verse to balance with the first half is "menders, sewers together of nothing" i.e. futility. The advice given to Job is deceit and futility.

The only unequivocal reference to physicians in the Hebrew Scriptures appears in the post-exilic writing of the Chronicler who records that Asa, king of Judah, when he became sick of a disease of the feet, consulted the rof'im. In doing so he failed to consult the Lord as the sole source of healing and as a result died (2 Chronicles 16:12). Although unacceptable, the physician is clearly recognized for his healing skill, doubtless reflecting a later situation, ${ }^{25}$ since the Book of Chronicles along with Ezra and Nehemiah are generally accepted as belonging to the post-exilic or Persian period. ${ }^{26}$ Moreover, it is noteworthy that the pre-exilic account of the same incident simply records that the king in his old age was diseased in his feet and died, without reference to physicians (1 Kings 15:23, 24). Hostility to rof'im in the case of King Asa stemmed, not only from their usurpation of God's healing role, but also from their possible involvement with alien magical practices with which Israel would have had contact during exile in Babylon ${ }^{27}$ or as a diasporate community following exile. ${ }^{28}$

Physicians are found mentioned in the apocryphal Book of Tobit. But this narrative, although set in the period of Assyrian captivity, has been assigned by modern scholarship to a later date, ${ }^{29}$ possibly the third century $\mathbf{B C} .^{30}$ Yet although

\footnotetext{
${ }^{24}$ Nordheim, op. cit., note 22 above, pp. 51-2, in the writer's view, completely misses the point by taking rof' $e$ 'elil as, not only evidence of the existence of physicians, but also of a standard whereby efficiency could be judged: "Anscheinend gab es also Kriterien um taugliche von untauglichen 'rophim' zu unterscheiden".

${ }^{25} \mathrm{E} \mathrm{L}$ Curtis and A A Madsen, $A$ critical and exegetical commentary on the Books of Chronicles, Edinburgh, T \& T Clark, 1910, p. 390 , note that this reference to physicians is unique in the Hebrew Scriptures and conclude that possibly the passage reflects the activity of physicians in the Chronicler's time.

${ }^{26}$ See Peter R Ackroyd, The chronicler in his age, Sheffield, Journal for the Study of the Old Testament, 1991, pp. 8-86, who indicates older material in Chronicles being represented to suit the post-exilic age of Persian rule. Curtis and Madsen, op. cit., note 25 above, pp. 5-6, place the Books of the Chronicles at the close of the fourth century BC.

${ }^{27}$ See E A W Budge, Babylonian life and history, 2nd ed., London, Religious Tract Society, 1925, pp. 215-18. In contrast to ancient Israel, the physician was well known from earliest times
}

in Babylon, as witnessed in the Code of Hammurabi dating from $c .1700 \mathrm{BC}$.

${ }^{28}$ Physicians were known to operate at the highest level of society around the time the Chronicler was writing, as Herodotus records in his account of the Greek physician, Democedes, who healed the infected leg of Darius I (522-486) and became a court favourite. See Herodotus, History, Bk 3: 130-4 (Herodotus, vol. 2, transl. A D Godley, Loeb Classical Library, 4 vols, London, W Heinemann; New York, G P Putnam's, 1920-24, pp. 160-7.)

${ }^{29}$ The book's errors of "fact" have been a major reason for scholars' denying its historicity, e.g. the tribe Naphtali was taken into exile by Tiglath-Pileser III (745-705 BC), 2 Kings 15:29, not Shalmaneser V (1:2). Sargon II (722-705 BC), not Sennacherib (1:15), was the successor to Shalmaneser V, although 2 Kings 17:1-6 and 18: 9-13 make the same mistake. The journey between Rages and Ecbatana, which Tobias accomplished in "two full days" (5:6), is, in fact, a distance of at least 185 miles.

${ }^{30} \mathrm{~F}$ Zimmerman, The Book of Tobit: an English translation with introduction and commentary, New York, Harper, 1958, pp. 21-7, 


\section{Nigel Allan}

the book may in all probability originate from this period, ${ }^{31}$ the writer skilfully drew from well-known folklore with much of which both he and his audience were familiar. ${ }^{32}$

Tobit is depicted as a devout Jew, living under Assyrian rule in Nineveh where he performed many acts of charity including the illicit burial of fellow Hebrews for which he was punished but later restored to his position and prosperity. However, in spite of what had occurred, Tobit persisted and, having buried a murdered Israelite, bathed $\mathrm{d}^{33}$ and then slept in the courtyard, unaware of sparrows nesting on the wall above. Their droppings fell on Tobit's eyes, impairing his sight with white films, i.e. cataract. ${ }^{34} \mathrm{He}$ consulted physicians, who prescribed ointments but their prescriptions only aggravated the condition till finally Tobit lost his sight $(2: 10){ }^{35}$ In contrast to Exodus 15:26, Tobit's blindness is not the result of disobedience to God's law, indeed the narrative is at pains to describe Tobit as a righteous man. Rather, God makes use of natural causes to demonstrate his powers. ${ }^{36}$ The physicians, as in the Book of Chronicles, are acknowledged as a distinct professional group but, here, Tobit is not punished for his lack of faith in the Lord's healing powers as in the instance of Asa, king of Judah. There is no hint of divine disapproval for consulting physicians,

points to the Seleucid period during the time of Antiochus IV (d. 165 BC) when Jews were forbidden to bury their dead. W O E Oesterley, An introduction to the books of the Apocrypha, London, SPCK, 1958, p. 169, argues for a date towards the end of the third century $\mathrm{BC}$. $\mathrm{M}$ Rabenau, Studien zum Buch Tobit, Beiheft zur Zeitschrift für die alttestamentliche Wissenschaft, vol. 220, Berlin, Walter de Gruyter, 1994, p. 175, claims the book was written in the middle of the third century $\mathrm{BC}$ with later additions. Carey A Moore, Tobit: a new translation with introduction and commentary, New York, Doubleday, 1996, pp. 39-42, argues for a date at the end of the third century BC. From the discovery of Hebrew and Aramaic fragments at Qumran, it is possible that the book was originally written in one of these languages, so supporting Jerome's claim that he produced his Latin translation from an Aramaic original. Zimmerman, ibid., pp. 139-49, argues for an Aramaic original from evidence of the Semitic style of the Greek versions and contends further that the Hebrew version was a translation from the Aramaic while Oesterley, ibid., p. 161, claims Hebrew as the original language.

${ }^{31}$ P Deselaers, Das Buch Tobit. Studien zu seinen Entstehung, Komposition und Theologie, Freiburg, Schweiz, Universitätsverlag; Göttingen, Vandenhoeck \& Ruprecht, 1982, in a very detailed and complicated analysis, attempts to identify several stages in the redaction of the original, which he places in the third century BC, see pp. 342-493.

${ }_{32}$ Several tales from folklore current at the time of composition have been utilized by the author, e.g. "the monster in the bridal chamber", "the grateful dead", see Zimmerman, op. cit., note 30 above, pp. 5-12; Moore, op. cit., note 30 above, pp. 11-14. J C Greenfield, 'Ahiqar in the Book of Tobit', in M Carrez, $\mathbf{J}$ Doré, $\mathbf{P}$ Grelot (eds), De la Tôrah au messie. Études d'exégèse et d'herméneutique bibliques offertes à Henri Caselles pour ses 25 années d'enseignement à l'Institut Catholique de Paris, Paris, Desclée, 1981, pp. $329-36$, pp. 333-4, argues that Ahikar, the hero of a story found in several forms in the ancient Near East, not only influenced the Book of Tobit but served as a foil for the Tobit narrative and its didactic purposes. See also J M Lindenberger, 'Ahiqar (seventh to sixth century BC): a new translation and introduction', in $\mathrm{J} \mathrm{H}$ Charlesworth (ed.), The Old Testament Pseudepigrapha, 2 vols, London, Darton, Longman \& Todd, 1985, vol. 2, pp. 479-507.

${ }^{33}$ In accordance with the Laws concerning ritual purity, see Num. 19:14-22.

${ }^{34}$ The Greek word used for white film, $\lambda \epsilon u ́ \kappa \omega \mu \alpha$, denotes a white spot in the eye caused by a thickening of the cornea. See H G Liddell and R Scott, A Greek-English lexicon, 6th ed., Oxford, Clarendon Press, 1869, p. 927.

${ }^{35}$ So Codex Sinaiticus. Codex Vaticanus

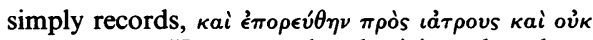
$\dot{\omega} \varphi \in \lambda \eta \sigma a ́ v \mu \epsilon$, "I went to the physicians, but they did not help me".

${ }^{36}$ See L P Hogan, Healing in the second temple period, Novum Testamentum et Orbis Antiquus, 21, Freiburg, Schweiz, Universitätsverlag; Göttingen, Vandenhoeck \& Ruprecht, 1992, p. 30 . 


\section{The Physician in Ancient Israel}

although their remedies resulted in Tobit's complete blindness. Yet, although physicians were recognized for their healing skills and could be consulted without fear of divine retribution, they are clearly not regarded as instruments of God's healing. The narrative leaves this to another.

The narrator now takes up the story of Sarah and so moves to Ecbatana in Media where Sarah, who had been given in marriage seven times, had never been able to consummate any of the marriages since on each occasion the bridegroom had been killed by the demon Asmodaeus. ${ }^{37}$ Sarah prays that she may be released from her misfortune at the same time as Tobit prays that God may take away his life so connecting the plight of both. Their prayers are answered and the angel, Raphael, ${ }^{38}$ is sent from the heavenly presence to cure them of their troubles $(3: 16,17)$.

The tale moves on. Tobit sends his son, Tobias, to retrieve silver he had deposited in Media (ch. 4). Tobias seeks and finds a kinsman, Azariah, literally "God helps" which is an alias for Raphael, to act as a travelling companion. ${ }^{39}$ The significance of Raphael's name "God heals" makes explicit his mandate (ch. 5). The narrative continues; while Tobias was bathing in the river Tigris, a huge fish jumped out of the river and tried to swallow his foot. Raphael ordered Tobias to seize the fish, split it open, discard the guts and preserve the gall, heart and liver (6:1-5). Having consumed half the fish, ${ }^{40}$ Raphael explained to Tobias that the heart and liver of the fish were used as material for fumigation to drive out demons and evil spirits. The use of vile smelling smoke to exorcize an evil spirit was well known in the ancient world. ${ }^{41}$ The angel also described to Tobias the use of gall for anointing the eyes

\footnotetext{
${ }^{37}$ This is the first appearance in Jewish literature of the demon Asmodaeus who became prominent in Talmudic, Christian and later Jewish writings, cf. b Gittin 68 ab; b Pesahim 110a. See The Testament of Solomon, ed. C C McCown, Leipzig, J C Hinrichs, 1922, 5:7 (p. 23, Greek text), where Asmodaeus claims to plot against the newly wed, "I mar the beauty of maidens and estrange their hearts". Asmodaeus is identified with the Persian sky demon, Aeshma Deva, one of six arch-fiends in the service of Angra Mainyu, the "Prince of Evil", and has under him seven especially powerful demons, see Oesterley, op. cit., note 30 above, pp. 166-7. J H Moulton, Early Zoroastrianism, the origins, the prophet, the magi, Hibbert Lectures, 1912, Amsterdam, Philo Press, 1972 (reprint of 1913 ed.), pp. $247-53$ and $333-40$, points out that the writer of Tobit relied heavily on late Persian religion, i.e. Magianism.

${ }^{38}$ Raphael, meaning "God heals", belongs to a heavenly world $(3: 16-17 ; 12: 15)$, bound to a determined hierarchy of angels. He is commissioned as God's agent and sent to discharge the divine plan. $\mathrm{He}$ is also commissioned by men since he bears their prayers to God (see 12:12-15). The angel serves to emphasize the transcendance and world sovereignty of God. See Deselaers, op. cit., note
}

31 above, pp. 368-9.

${ }^{39} \mathbf{R}$ Pautrel and $\mathbf{M}$ Lefebvre, 'Trois textes de Tobie sur Raphaël (Tob. V, 22; III, 16 s.; XII, 12-15)', Recherches de Science Religieuse, 1951/ 52, 39: 115-25, pp. 116-17. Compare Raphael's role as guardian angel to the angel in Gen. 24:7, 40 , who went before Eleazer on his journey to Nahor to seek a wife for Isaac. It is noteworthy that the name Azariah given to the angel, Raphael, in his role as companion of Tobias, is modelled on that of Eleazer since one of Raphael's roles is to see Tobias safely married to his kinswoman.

${ }^{40}$ The rest was kept and salted, not to preserve the fish for future eating, but to ward off malevolent spirits since salt was almost universally regarded as repugnant to demons. Salt was one of the basic necessities of life (see Sira 39:26) and served a variety of purposes in the Hebrew Scriptures, but here the magical use of salt is appropriate to the context. Salt had magical properties and would control any injurious magic left in the disjecta membra of the fish. Cf. E Jones, 'The symbolic significance of salt and superstition', in Essays in applied psychoanalysis, 2 vols, London, Hogarth Press, 1951, vol. 2, pp. 29-30.

${ }^{41}$ See F Lexa, La Magie dans l'Égypte antique, 3 vols, Paris, Paul Geuthner, 1925, vol. 1, p. 104. 
and relieving blindness. Fish gall as a prescription for blindness was also well known in the ancient world, as witnessed in Assyria where the gall of the Kuppũ fish was mixed with either butter or salt to make an eye salve. ${ }^{42}$

As they approach Ecbatana, Raphael explains the predicament of Raguel's daughter, Sarah, and how Tobias, as her next of kin, must marry her in accordance with Mosaic law (Deuteronomy 25:5). On arrival at Raguel's house, they are well received and Tobias asks and receives the hand of Sarah (ch. 7). On the bridal night Tobias burns the heart and liver of the fish, as instructed by Raphael, and as a result of the smell ${ }^{43}$ the demon flees to upper Egypt. ${ }^{44}$ One healing accomplished in Ecbatana, the second occurs back in Nineveh. Tobias returns with his new wife and travelling companion, Raphael, who instructs Tobias to "apply the gall, leave it some time, after which the white film will go" (11:8). In doing so Raphael takes on the role of a physician prescribing medical treatment. Tobit's sight restored, celebrations follow and in the ensuing discussion on how Raphael should be compensated, he reveals his identity, making it clear that God sent him to cure both Tobit and his daughterin-law, and in this God is to be praised for all he has done (ch. 12).

Although Tobit and his family are shown as pious Jews observant of the Mosaic law, they were subject to the alien influences that surrounded them. The demon Asmodaeus has been associated with the Persian sky demon Aeshma Deva, and exorcism by fumigation, recorded for the first time in Israel in the Book of Tobit, possibly originated in Egypt. ${ }^{45}$ The magical nature of the procedure is supported by the predicate $\lambda \hat{v} \sigma a \iota$ in the Sinaiticus version as a technical term employed in magic to denote the freeing of a victim from a demon. ${ }^{46}$ Both the magical and medical uses of the fish were well known to both writer and audience and the commission of Raphael from God to cure Tobit and Sarah by these methods legitimizes their use

\footnotetext{
${ }^{42} \mathrm{~W}$ von Soden, 'Fischgalle als Heilmittel für Augen', Archiv für Orientforschung, 1966, 21: 81-2. Pliny the Elder (AD 23/24-79) also reported the use of fish gall as an ointment for the eyes, see Pliny the Elder, Natural History, Bk 32: 24 (Pliny, Natural History, Bks 28-32, transl. W H S Jones, Loeb Classical Library, London, W Heinemann; Cambridge, MA, Harvard University Press, 1963, pp. 506-11), and Galen mentions its use, see De simplicium medicamentorum

temperamentis ac facultatibus, X, 2, 13 (C Galen, Opera omnia XII, Hildesheim, Georg Olms, 1965, pp. 275-81).

${ }^{43}$ The Talmud, b Shabbat 110 a, gives a similar example of fumigation in the instance of a serpent entering the womb of a woman. The woman stood over a concoction of burning ingredients. When the serpent emerged from her womb, it was cast into a fire. While the serpent functions as an obvious impediment to sexual intercourse, the fumigation here, in contrast to Tobit, serves to attract rather than expel the malevolent spirit.

${ }^{44}$ Nine-tenths of the world's demons were thought to originate in Egypt, see b Kiddushin
}

49b. Upper Egypt was a wilderness area regarded as the residence of spirits and demons, cf. Deselaers, op. cit., note 31 above, p. 149, note 210.

${ }^{45}$ Parallel evidence for anti-demoniac burning of fish entrails may be found in the fourth book of Kyranides, originating from Egypt and reaching back to the core of the Hellenistic period in which the burning of fish tongues and bones for the elimination of demons is recommended, cf. Kyranides $I V, 13,2-5$, which also includes an eye salve for blindness, 55, 1-4; for the elimination of demons by smells see Kyranides III, 51, 21. Die Kyraniden, ed. D Kaimakis, Meisenheim am Glan, Anton Hain, 1976 , pp. 252,283 and 239 , respectively.

${ }^{46}$ Liddell and Scott, op. cit., note 34 above, $p$. 949. P E Dion, 'Raphaël l'exorciste', Biblica, 1976, 57: 399-413, p. 407, suggests that as the Aramaic root patter is used in both secular Babylonian divorce documents and in religious exorcisms, Raphael, in exorcising the demon Asmodaeus (8:2), was actually divorcing Asmodaeus from Sarah. 
as appropriate to the will of God. The helplessness of the physicians serves to emphasize that health is solely within the gift of the Lord by whatever means he chooses to employ and it is significant that those means, although foreign to Israel, were well known and accepted in a narrative written for the edification of devout Jews.

The use of magical remedies by the Jews is well attested in the pseudepigraphal literature. In the Book of Watchers, which comprises the first thirty-six chapters of the Ethiopic Book of Enoch and possibly dates from the first half of the second century $\mathrm{BC}$, there is an account in chapters six to eleven of the fallen angels which is thought to derive from a 'Book of Noah', ${ }^{47}$ a suggestion that has found added support in recent times from the discovery of a similar fragment at Qumran. ${ }^{48}$ These angels, having cohabited with humans (cf. Genesis 6:2), produced a race of giants who proliferated the earth with sin (ch. 7). They taught a knowledge forbidden by God, including information relating to root cuttings and plants $(7: 1 ; 8: 3)$, which in antiquity were frequently associated with magic. ${ }^{49}$ The text of the Greek Syncellus

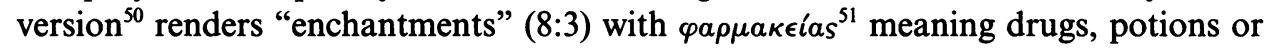
spells, including witchcraft or magic that carries away disease. At the request of the archangels, God commissioned Raphael to cast the leader of the race of giants into a desert cavern, to heal the earth, and to prevent the children of men perishing from the consequences of the forbidden knowledge they had received. ${ }^{52}$ Raphael is found in a further section of the Book of Enoch known as the Book of Similitudes or

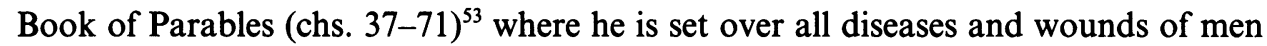
$(40: 9) .{ }^{54}$ In the Book of Jubilees, probably dating from the middle of the second century $\mathrm{BC},{ }^{55}$ demons, who were leading the sons of Noah astray $(10: 2-14)$, were bound except for one-tenth who were permitted to remain. One of these, commissioned by

${ }^{47} \mathrm{R}$ A Charles, The Book of Enoch: or I Enoch, Oxford, Clarendon Press, 1912, pp. xi, xlvii, lii, assigns chs $6-11 ; 54: 17-55: 2 ; 60 ; 65-69: 25 ; 106$ and 107 to the Book of Noah.

${ }^{48}$ The discovery of Aramaic fragments of the Books of Enoch at Qumran dating from the first half of the second century BC gives a terminus ad quem to the book. See J T Milik (ed.), The Books of Enoch; Aramaic fragments of Qumran Cave 4, Oxford, Clarendon Press, 1976, pp. 59-69.

${ }^{49}$ See E A W Budge, Herb doctors and physicians in the ancient world, Chicago, Ares, 1978, pp. 37-8 (reprint of 1927 ed.).

${ }^{\text {so }} \mathrm{M}$ Black (ed.), Apocalypsis Henochi graeci, Leiden, E J Brill, 1970, p. 22.

${ }^{51}$ Liddell and Scott,op. cit., note 34 above, pp. 1741-2.

${ }^{52} \mathrm{~A}$ possible word play has been suggested on the word $r f^{\prime}$ to bind Azazel, and to heal the earth $(10: 4,7)$ by Milik (ed.), op. cit., note 48 above, $p$. 316 , who, although these verses are missing in the Aramaic fragment, makes the conjecture from the rest of the existing fragment.

${ }^{53}$ The absence of this section from the Qumran fragments has led Milik (ed.), op. cit., note 48 above, pp. $89-96$, to date it around $A D$ 270, while D W Suter, 'Weighed in the balance: the similitudes of Enoch in recent discussion', Religious Studies Review, 1981, 7 (3): 217-20, places it in the first century $\mathrm{AD}$.

${ }^{54}$ There is much confusion on the function and hierarchy of angels. In En. 20:3 and 22:1-14 Raphael is placed over the spirits and souls of the dead. In En. 20:7 Gabriel is given charge over Paradise, the serpents, and the Cherubim, but in En 32:6 Raphael describes to Enoch the tree of wisdom from which Adam and Eve ate and so discovered their nakedness. See Zimmerman's attempt to sort out the confusion relating to Raphael's function (op. cit., note 30 above, pp. 150-1).

${ }^{55}$ For a discussion on the dating of the Book of Jubilees see G W E Nickelsburg, Jewish literature between the Bible and the Mishnah: a historical and literary introduction, London, SCM Press, 1981, pp. 78-9. Hogan (op. cit., note 36 above, pp. 83-4) suggests that Jubilees 10 is drawn from the Book of Watchers, whose traditions it revises. 
God, explained to Noah all the medicines for their diseases and how they might be healed with the herbs of the earth. This information Noah committed to writing and passed on to his son Shem. ${ }^{56}$ It is significant that, in contrast to the Book of Watchers, the forbidden knowledge of medicines is sanctioned here by God so that illness with its demoniac origin in man being led astray, i.e. sin (v. 2.), is provided with an antidote in magical remedies prescribed by a demon. This emphasizes the general ambivalence towards magical practices from Israel's earliest period ${ }^{57}$ until Talmudic times when the use of Solomon's seal is mentioned. ${ }^{58}$ Its use was witnessed by Josephus in the presence of the Emperor Vespasian when one, Eleazer, exorcized demons by means of a ring using incantations composed by Solomon. ${ }^{59}$ On the other hand, King Hezekiah was praised by the rabbis for concealing a book of medicines associated with Solomon. ${ }^{60}$

The Essenes, a Jewish sect that flourished from around the second century $\mathbf{B C}$ until the first century AD and have been associated with the community at Qumran, ${ }^{61}$ took a keen interest in medical matters. It has been argued that their name derived from the plural form of the Aramaic word 'āsyā, "the healers", ${ }^{22}$ but a more probable derivation comes from the plural of the Aramaic hasya "the holy" or "pious ones". ${ }^{63}$

According to Josephus they followed a way of life based on the teachings of Pythagoras, ${ }^{64}$ so, although a Jewish sect, they were deeply influenced by Greek

${ }^{56} \mathrm{~A}$ 'Book of Noah' is mentioned in the Hebrew text Sefer refu'ot, 'Book of Medicines', possibly dating from the tenth century $\mathrm{AD}$ and attributed to a Jewish "sage" Asaf. It is referred to as the "Book of Shem, the son of Noah". In it Raphael gives detailed instruction in the medical use of trees, herbs, roots and seeds. See A Jellinek, Bet ha-Midrasch, 2nd ed., 2 vols, Jerusalem, Bamberger \& Wahrman, 1938, pt 3, vol. 1, pp. XXX-XXXIII, 155-60.

${ }^{57}$ As has been seen in the ritual cleansing of the "leper" (Lev. 14:1-9) and the magical cures prescribed in the Book of Tobit.

${ }^{58}$ See b Gittin $68 \mathrm{ab}$. According to the Testament of Solomon, op. cit., note 37 above, 1: $5-7$, the ring was given to Solomon by the archangel Michael at God's command. This work, dating from $c$. AD 100-400, reflects details of medicine and magic current among JudaeoChristian communities during the early Christian centuries. See ibid., pp. 105-8.

${ }^{59}$ Flavius Josephus, Jewish antiquities, Bk 8: 42-49 (Josephus, Jewish antiquities, Bks 5-8, vol. 5 , transl. H St J Thackeray and R Marcus, Loeb Classical Library, London, W Heinemann; Cambridge, MA, Harvard University Press, 1934, pp. $592 \mathrm{ff})$.

${ }^{60}$ For Hezekiah's concealment of a book of medicines, see b Pesahim 56a.

${ }^{61}$ This view is maintained on the basis of Pliny the Elder, Natural history, Bk 5:15 (Pliny,
Natural history, vol. 2, Bks 3-7, transl. H Rackham, Loeb Classical Library, London, W Heinemann; Cambridge, MA, Harvard University Press, 1942, pp. 276-7), who located the Essenes on the north-western shore of the Dead Sea above 'En Gedi and Masada, which fits in with the ruins discovered at Qumran. See M Black, The scrolls and Christian origins: studies in the Jewish background of the New Testament, London, T Nelson, 1961, pp. 3-13.

${ }^{62}$ See G Vermes, 'The etymology of the "Essenes"', Revue de Qumran, 1960, no. 7, vol. 3, fasc. 4, pp. 427-43; ibid., 1962, no. 12, vol. 3, fasc. 4, pp. 495-504.

${ }^{63}$ See E Schürer, The history of the Jewish people in the age of Jesus Christ (175 BC-AD 135), rev. ed. by $\mathrm{G}$ Vermes, F Millar, M Black, Edinburgh, T \& T Clark, 1979, vol. 2, p. 559.

${ }^{64}$ Josephus describes the Essenes as a group which "follows a way of life taught to the Greeks by Pythagoras", Jewish antiquities, 15: 371 (Josephus, Jewish antiquities, Bks 15-17, vol. 8, transl. R Marcus, completed and ed. A Wikgren, Loeb Classical Library, London, W Heinemann; Cambridge, MA, Harvard University Press, 1963, pp. 178-9). See H Serouya, 'Les Esséniens; secte mystique et thérapeutique', Revue d'Histoire de la Médecine Hébraïque, 1951, 11: 5-17; 1952, 12: 5-19; 1952, 13: 61-9. 


\section{The Physician in Ancient Israel}

philosophy. Their interest in healing included research into medical remedies relating to roots and stones preserved in the writings of the ancients. ${ }^{65}$ This, together with the fact that novices entering the community were required to "preserve the books of the sect and the names of the angels", ${ }^{66}$ indicates that, although they may well have used rational remedies, they also engaged in occult practices ${ }^{67}$ of angelic or demoniac origin, so maintaining the traditions preserved in Enoch, Jubilees and in other writings in circulation at this period. Philo's interesting comment, however, that communal funds were used to pay for treatment of the sick, implies that professional medical help from outside the community was called upon, since it is unlikely that, as they held "all things in common", 68 treatment from within the community would have been paid for. ${ }^{69}$

The remarks of Josephus regarding the influence of Pythagoras on the life style of the Essenes shows the pervasive influence of Greek philosophy and culture on Judaism during this period, which had even permeated a Jewish sect. The initiative towards Hellenization ${ }^{70}$ came from the indigenous Semitic and Egyptian populations who, anxious to improve their social and economic status, adopted the Greek language, education and life style, ${ }^{71}$ a development mirrored in the Wisdom of Jesus ben Sirach. This work is generally regarded to have been written around the beginning of the second century BC, and was translated some fifty years later by the author's grandson in Egypt, presumably to make it available to Greek-speaking Jews in

\footnotetext{
${ }^{65}$ Flavius Josephus, The Jewish war, Bk 2: 136 (Josephus, The Jewish war, Bks 1-3, vol. 2, transl. H St J Thackeray, Loeb Classical Library, London, W Heinemann; New York, G P Putnam's, 1927, pp. 374-5).

${ }^{66}$ Josephus, The Jewish war, Bk 2: 142 (Josephus, ibid., pp. 376-7). Incantation bowls dating from the Talmudic period frequently mention angels, see J Naveh and S Shaked, Amulets and magic bowls: Aramaic incantations of late antiquity, Leiden, E J Brill, 1985, especially pp. 50-1, Amulet 3, pp. 68ff, Amulet 7.

${ }^{67}$ See S Kottek, 'The Essenes and medicine', Clio Medica, 1983, 18: 81-99, pp. 82-5. Roots, as we have seen, could be used magically, as could stones, as illustrated, for example, in the tradition preserved in the Talmud that the sick on looking at a precious stone hung round the neck of Abraham recovered, b Baba Bathra 16b. Both roots and stones appear in ancient materia medica, see Dioscorides, Materia medica, Bk 5 , chs 84-183 (R T Gunther, The Greek herbal of Dioscorides, London, Hafner, 1968, pp. 623-60).

${ }^{68}$ Philo, Quod omnis probus liber sit, 12:87 (Philo, vol. 9, transl. F H Colson, Loeb Classical Library, London, W Heinemann, Cambridge, MA, Harvard University Press, 1941, pp. 60-1).

${ }^{69}$ Therapeutae, a sect thought to have similar roots to the Essenes, but who lived by the
}

Mareotic Lake near Alexandria, led a life of contemplation, study and fasting. See Philo of Alexandria: the contemplative life, the giants, and selections, transl. and intr. D Winston, London, SPCK, 1981, pp. 41-57. They were the epitome of spiritual healing, but Philo, who alone mentions them, does not record them having any interest in healing remedies as the Essenes-see De vita contemplativa, 28-29 (Philo, op. cit., note 68 above, pp. 128-9), although he claims they derived their name from the Greek $\theta \epsilon \rho a ̆ \pi \epsilon i a$ in the sense of caring, not merely for the body but for the soul, so De vita contemplativa, 2 (ibid., pp.

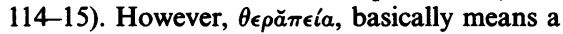
worshipper or servant and in a medical context service done to the sick, see Liddell and Scott, op. cit., note 34 above, pp. 698-9.

${ }^{70}$ The first attested use of the word $\dot{\epsilon} \lambda \lambda \eta \nu \iota \sigma \mu$ os occurs in 2 Macc. 4:13 and refers to the adoption of Greek customs by the Jews of Jerusalem including participation in the games at the Greek gymnasium.

${ }^{71}$ See Martin Hengel, Jews, Greeks and barbarians: aspects of the Hellenization of Judaism in the pre-Christian period, transl. John Bowden, London, SCM Press, 1980, pp. 74ff; W B Davies and L Finkelstein (eds), The Cambridge history of Judaism, vol. 2, Hellenistic age, Cambridge University Press, 1984, pp. 181ff. 
Alexandria. ${ }^{72}$ As a teacher of wisdom, ${ }^{73}$ Sirach brought together the zeal for Jewish wisdom with Hellenistic culture which challenged ancestral beliefs. ${ }^{74} \mathrm{He}$ protested against the arrogance of the Hellenized aristocracy in Jerusalem ${ }^{75}$ in their haphazard observance of the Torah ${ }^{76}$ yet he could value riches, ${ }^{77}$ was familiar with the etiquette of Greek meals ${ }^{78}$ and praised the reputation and political significance of the wise man who travels to foreign lands on behalf of the great (34:9-12). Sirach therefore provides an insight into the cultural and religious ethos during the years leading up to the Maccabean period of nationalist fervour.

It is in this context that Sirach brought the role and function of the physician to the attention of his pupils in an accommodation of the practice then current in the Hellenized Jewish circles of Jerusalem with the traditional view that healing was the exclusive preserve of God. ${ }^{79}$ The celebrated passage relating to the physician (38: $1-15$ ) is in three distinct sections. The first, verses $1-3$, begins with an imperative whereby the physician is to be delighted in, so implying that prejudice is to be overcome since God has created him. In the use of the predicate $h l q$ in the second part of the first verse in the Hebrew text to denote "create", the verb is employed in the sense "to order", "to assign", or "to allot", stressing that the medical

\footnotetext{
${ }^{72}$ In his prologue to the Greek translation, the author's grandson states that he came to Egypt in the thirty-eighth year of the reign of King Euergetes. In The wisdom of Ben Sira: a new translation with notes, by $\mathrm{P}$ W Skehan, introduction and commentary by A A Di Lella, New York, Doubleday, 1987, p. 8, it is pointed out that only two Lagid kings bore the epithet "Euergetes", the dates of the second, Ptolemy VII Physkon, fitting in with the chronology of the book. This places the original composition of the work in Hebrew by Sirach about fifty years earlier, i.e. $180 \mathrm{BC}$, a conclusion reached by A A di Lella, The Hebrew text of Sirach: a text-critical and historical study, The Hague, Mouton, 1966, pp. 150-1. Martin Hengel, Judaism and Hellenism: studies in their encounter in Palestine, transl. John Bowden, London, SCM Press, 1974, vol. 1, pp. 133-4, argues that Sirach's plea for the Oniads and for the privileges of the descendants of Aaron and Phinehas (50:23-4, Hebrew text) indicate that these were in dispute, which fits the situation facing Onias III in his struggle with Seleucus IV Philopater in Antioch and wealthy Jewish families, cf. 7:4-7, and concludes that the book was completed directly before the accession of Antiochus IV in $175 \mathrm{BC}$. See also J Marböck, Weisheit im Wandel: Untersuchungen zur Weisheitstheologie bei Ben Sira, Bonn, Peter Hanstein, 1971, p. 9.

${ }^{73}$ Sirach spoke of his teaching house, bet midrash, 51:23. Skehan, op. cit., note 72 above, $p$. 10 , describes Sirach as the last of the wise men of Israel and the first of the scribes.

${ }^{74}$ See R A Kraft and G W E Nickelsburg (eds), Early Judaism and its modern interpreters,
}

Philadelphia, Fortress Press; Atlanta, GA, Scholars Press, 1986, p. 372.

${ }^{75}$ The economy of Jerusalem was based mainly on rural industries and dependent on the Temple. Artisans, such as the smith, potter, and perfumer, provided the tools and luxuries used by the city and rural communities, and animal sacrifice turned the Temple into the most important purveyor of the basic commodity of the leather trade. Although foreign traders came to Jerusalem and Judaea, they were not on the main caravan routes, nor was Jerusalem a financial centre. See E J Bickerman, The Jews in the Greek age, Cambridge, MA, Harvard University Press, 1988, pp. 148ff.

${ }^{76}$ Sira $5: 1-4,6 ; 41: 8,9 ; 42: 2$.

${ }^{77}$ Sira $10: 27 ; 13: 24$.

${ }^{78}$ Sira 31:25-32:6. Sirach understands the meal and drinking as a gift from God and a time for relaxing with friends, see Oda Wischmeyer, Die Kultur des Buches Jesus Sirach, Beihefte zur Zeitschrift für die neutestamentliche Wissenschaft und die Kunde der älteren Kirche, vol. 77, Berlin and New York, Walter de Gruyter, 1994, p. 106. Marböck, op. cit., note 72 above, p. 162-3, points out that the Hebrew Scriptures opposed conviviality. Eating and drinking belonged to the great national occasions, e.g. the dedication of the Temple (1 Kings 8:65-66), or the roll call of Ezra (Neh. 8:10-12). The mention of a master of ceremonies at a feast (Sira 32:1-2) is one of the earliest evidences of this Hellenistic custom in Jerusalem.

${ }^{79}$ Wischmeyer, op. cit., note 78 above, p. 47 , note 55 , suggests that Sirach himself may have been a physician. 


\section{The Physician in Ancient Israel}

practitioner with his healing skills is part of the all-embracing order of creation, as Sirach states in verses 6 and 8 , yet also indicating by implication a certain hostility to the physician. Emphasis is laid on the wisdom of the physician which comes from God and is acknowledged by kings (v. 2), but although Sirach warns against royal service $(7: 4,5)$, he saw such service as an activity appropriate for the wise, perhaps reflecting his own past.

Having established the physician as a channel of God's healing power, Sirach turns to the tools of that power. These tools are the medicines brought from the earth, the Hebrew terufot "medicines" being rendered in the Greek text with the

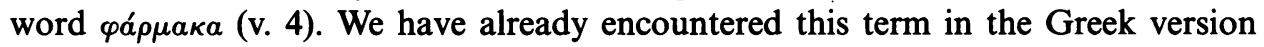
of Enoch 8:3 with reference to forbidden knowledge relating to root cuttings and plants with medicinal properties where it had a magical connotation. Similar information relating to plants ${ }^{80}$ and other substances is found in the Testament of Solomon, possibly dating from the early Christian centuries ${ }^{81}$ and, as noted above, Josephus attributed to King Solomon a considerable knowledge of medicine and stressed magical cures. Later rabbinic tradition, taking up Sira 38:4, 7-8, in a discussion on the purposefulness of the world, based the curative powers of healing herbs on astrological constellations and sympathy with the stars. ${ }^{82}$ One of the areas in which the Hellenistic world was particularly interested concerned the Jewish tradition of magic. Solomon ${ }^{83}$ along with Moses $^{84}$ came to be regarded in the Hellenistic-Roman world as one of the great teachers of secret knowledge long before the first Greek philosophers. ${ }^{85}$ Indeed, the Jews were universally held as "a race expert in the magical arts" ${ }^{86}$ Here Sirach's grandson, in the use of the word ча́рнака, embraces the medicaments current in Alexandria along with Jewish folk

\footnotetext{
${ }^{80}$ See Testament of Solomon, op. cit., note 37 above, especially $6: 10,17: 20,33$ (pp. 27-8, 55, 57-8 Greek text).

${ }^{81}$ Testament of Solomon, op. cit., note 37 above, pp. 106-7.

${ }^{82}$ Midrash Rabbah Genesis 10:6 (Midrash Rabbah, Genesis, transl. and ed. H Freedman, London, Soncino Press, 1939, vol. 1, pp. 74-5).

${ }^{83}$ According to Josephus, Solomon "philosophized" about the whole of nature, though from the thinking of the Hellenistic period, this all-embracing wisdom could only be understood in a magical sense. See Flavius Josephus, Jewish antiquities, Bk 8:44 (Thackeray and Marcus translation, op. cit., note 59 above, pp. 594-5.)

${ }^{84}$ In the classical world, Moses was regarded not only as a great law giver but even more as the arch-magician. It was purely in the field of magic and astrology that a complete fusion between Jews and pagans occurred from the second century BC. See Davies and Finkelstein (eds), op. cit., note 71 above, vol. 2, pp. 203-6; also J G Gager, Moses in Greco-Roman
}

Paganism, Nashville, Abingdon Press, 1972, pp. 134-61.

${ }^{85}$ The Jewish "peripatetic" Aristobulus writing about $170 \mathrm{BC}$ regarded Solomon as one of his philosophical predecessors, whose acuteness of expression outstripped the peripatetic school of philosophy, see Eusebius, Evangelicae praeparationis, Bk 13, 12:11 (Eusèbe de Césarée, La Préparation évangélique, Livres XII-XIII ... ed. E des Places, Paris, du Cerf, 1983, pp. 320, 321). This reputation enjoyed by Solomon derives from 1 Kings 3:12-15 in which God granted him his request for wisdom including a knowledge of the plant kingdom (1 Kings 4:29-34). Although a knowledge of medicine is not mentioned, the tradition associating Solomon with medicine clearly derives from his knowledge of plants.

${ }^{86}$ Origen, Contra Celsus, Bk 1, Ch. 26 (A Roberts and J Donaldson (eds), The Ante-Nicene fathers, vol. 4, Buffalo, The Christian Literature Pub. Co., 1885, p. 407). See J Hull, Hellenistic magic and the synoptic tradition, London, SCM Press, 1974, pp. 39-44. 
remedies, including magic, which so fascinated the non-Jewish populace ${ }^{87}$ It is difficult otherwise to explain the honour and respect accorded the Jewish physician by pagan patients (vv. 2,3 ) if he could offer only the standard medicine practised by his non-Jewish colleagues.

The type of medicine practised by Sirach's physician is possibly reflected in the Sefer refu'ot attributed to Asaf the physician which, although much later than Sirach with parts composed between the third and eleventh centuries $\mathrm{AD}^{88}$ is strongly Hippocratic, with material drawn from Dioscorides and elsewhere. Yet there is little evidence of Galenic influence, although Galen is mentioned as one of the four sages in the introduction. It claims, however, to have been given by Raphael to Noah who passed it on to his son, Shem, ${ }^{89}$ so drawing its authority from Jewish folklore. Since Sirach shows the physician in a favourable light for the first time in Jewish literature, and in doing so promotes a profession hitherto held in low esteem, as has been suggested by the apparent prejudice implied in verses $1-3$, the medicine practised by the Jewish physician would have had to have been an amalgam of Greek medicine and Jewish medico-magic folklore to achieve widespread acceptance in Judaism. It is in this tradition that Sirach's physician practised, drawing from his Jewish roots the same divine authority given in the Book of Tobit for remedies administered by Raphael, whose role is now transferred to the physician. We can imagine the urban Essene with his Pythagorean background being treated by a Jewish physician versed in both Greek medicine and Jewish folklore familiar to the patient. To root both the physician and his medicine in the Hebrew Scriptures, reference is made to the wilderness incident (v. 5) in which the bitter waters were made sweet by throwing a tree into the water (Exodus 15:23-25). It is noteworthy that Moses, so highly regarded in the classical world as a magician, brought this miracle about. As the tree revealed God's gift of the water's sweetness, so here the physician reveals the healing powers of God's medicines, all of which reflect God's glory (vv. 5-8). ${ }^{90}$

Having dealt with the physician, Sirach now turns in the third section to the patient. He advises against neglect of illness and exhorts prayer and penitence (vv.

\footnotetext{
${ }^{87} \mathrm{~F}$ Millar, 'The problem of Hellenistic Syria' in A Kuhrt and S Sherwin-White (eds), Hellenism in the East: the interaction of Greek and nonGreek civilizations from Syria to Central Asia after Alexander, London, Duckworth, 1987, pp. $110-33$, p. 132, states that, at least in an urban situation, there is adequate evidence to suggest that it was possible to absorb Greek culture without losing local traditions.

${ }^{88}$ See S Muntner, 'The antiquity of Asaph the Physician and his editorship of the earliest Hebrew book of medicine', Bull. Hist. Med., 1951, 25: 101-31, pp. 116-30. Muntner claims that, although the book of medicines hidden by King Hezekiah is not Asaf's Sefer refu'ot, several halakot were preserved in writing and freshly absorbed in Asaf's work. More recently, E Lieber in 'Asaf's Book of medicines: a Hebrew encyclopedia of Greek and Jewish medicine possibly compiled in Byzantium on an Indian
}

model', in John Scarborough (ed.), Symposium on Byzantine medicine, Washington, DC, Dumbarton Oaks Research Library and Collections, 1985, pp. 233-49, pp. 235-7, 243, suggests the book to be a product of Byzantine Italy and to have been in existence by the tenth century. Lieber describes it as "a blend of Jewish and Greek concepts tempered by the genius of an anonymous author".

${ }^{89}$ In Jubilees 10:7-12, it was the demon Mastema who was authorized to explain to Noah the use of herbs, see note 56 above.

${ }^{90}$ The text speaks of one who prepares ointments (v. 8, Heb. v. 7) rokeah, so distinguishing this functionary from the physician, cf. Exod. 30:35; Eccles. 10:1. The Greek text uses the word $\mu \check{v} \rho \epsilon \psi$ ós, one who boils and prepares unguents, see Liddell and Scott, op. cit., note 34 above, p. 1030. 


\section{The Physician in Ancient Israel}

9, 10) thus fixing his teaching firmly in the Hebrew Scriptures, maintaining that while God sends sickness as a result of sin, he also makes healing available, conditional on observance of the Law. Prayer and penitence find expression in sacrificial offering (v. 11) and Sirach's admonition to give generously may reflect his interest in the sacrificial worship of the Jerusalem Temple-indeed Sirach's interest in the Jerusalem priesthood is a feature of his work. ${ }^{91}$ As we have already seen in the sacrificial offering prescribed for the cleansed "leper" (Leviticus 14), here also a magical element is involved in which the sacrifice frees the patient from the demoniac

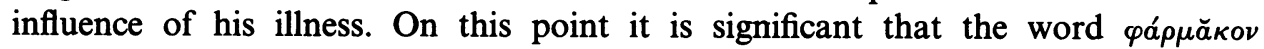
"medicines" in verse 4, can also refer to that which is slain to expiate the crimes of a city, ${ }^{92}$ analogous to the scapegoat in ancient Israel which carried away the sins of the nation to the wilderness (Leviticus 16:20-28). "Pour oil in thy abundance", literally "wings of thy substances (?)", be-kanfe honeka (?) in verse 11 of the Hebrew text may possibly suggest, in the use of the word kenef "wings" in the plural, a sacrificial offering of birds as in the case of the "leper" ${ }^{93}$ It is only when the patient has re-established his relationship with God, and therefore recovered his spiritual health fractured by sin, that Sirach orders the patient to call in the physician (v. 12) reiterating (v. 1) that the physician is part of God's creation. In again stressing this fact, an undercurrent of antagonism to the physician can be deduced. He too must pray for divine help in diagnosis, correct treatment and prolongation of life, yet again emphasizing that these are at God's behest. The final verse is difficult, but reiterates the traditional view that sin, as the cause of sickness, requires God's healing discharged by his agent, the physician, with the medicines of his creation. ${ }^{94}$

In Sirach, the physician, although a familiar figure, was apparently not wholly accepted in Jewish society. To gain acceptance, Sirach skilfully accommodated Hellenistic culture and medical knowledge with Jewish folklore, interpreting both the medicines and skills of the physician, as indeed the physician himself, as part of God's creation. In this coalescence of cultures, Greek medical practice was syncretized with Jewish folklore, the hitherto little regarded Jewish physician replacing the angel in the Book of Tobit as the channel of God's healing. This new status of the physician is reflected in the Septuagint's translation of Exodus 21:19, which has already been considered to contain no evidence of medical care being provided for the victim of

\footnotetext{
${ }^{91}$ In E P Sanders with A I Baumgarten and A Mendelson (eds), Jewish and Christian selfdefinition, vol. 2, Aspects of Judaism in the Graeco-Roman period, London, SCM Press, 1981, pp. $69-87$, the hostility of the conservative Romans to Hellenistic culture is contrasted with the positive view in which Jews held Greek customs, and it is argued that pious Jews did not believe the Hellenizing reforms of the High Priest, Jason, in 175/174 BC compromised the teachings of the Torah.

${ }^{92}$ See P Ghalioungui, Magic and medical science in Ancient Egypt, London, Hodder \& Stoughton, 1963, p. 35.

${ }_{93}$ The word $\pi \rho \circ \sigma \phi \circ \rho a$ used for offering in the Greek text is a synonym for tovoía, sacrificial
}

victim, cf. Sira 35:7; 46:16. See Liddell and Scott, op. cit ., note 34 above, pp. 1387 and 718. Moshe T Segal, Sefer ben Sira' ha-shalem, Jerusalem, Bialik Institute, 1953, p. 247 [Hebrew] renders it "according to your resources". To achieve this translation he amends be-kanfe honeka to kefi honeka.

${ }^{94} \mathrm{~J}$ T Neelis, 'Sirach 38:15', in W C Delsman et al. (eds), Von Kanaan bis Kerala: Festschrift für J. P. M. van der Ploeg zum Vollendung des siebzigsten Lebensjahres am 4 Juli, 1979, Neukirchen-Vluyn, Neukirchen, 1982, pp. 173-84, considers various variant readings in the Hebrew text and finally gives the unconvincing translation "the one who sins before God, let him be courageous before the physician". 


\section{Nigel Allan}

an assault. The Greek text explains almost by way of a "midrash" this obscure

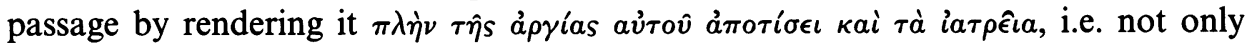
will the time of the victim be repaid but also his healing which, to the translator, meant the physician and which Josephus further interprets as the physician's fee. ${ }^{95}$ It is on this basis that the school of Rabbi Ishmael in the second century AD granted permission for the practice of medicine,${ }^{96}$ so establishing the role of the physician in Judaism.

From the Christian Scriptures it is clear that physicians were acknowledged in the Holy Land at that time if only in passing, and it is evident that Jesus viewed himself as having the reputation of a healer ${ }^{97}$ in the tradition of Elijah and Elisha (Luke 4: 21-30). ${ }^{98}$ The Gospel accounts of miraculous healings are spoken of as "signs" with the purpose of witnessing to Christ's messianic credentials and regarded as the fulfilment of the prophecies contained in the Hebrew Scriptures. ${ }^{99}$ However, the professional healer in his role of physician stands apart from the miracle worker, as is quite clear from the account of the woman with an issue of blood who, at great expense but without success, had consulted many physicians before coming to Jesus. ${ }^{100}$ This incident also shows that the physician, although acknowledged, was not regarded as the sole means of healing. St Luke is described as the "beloved physician" (Colossians 4:14), a description the vocabulary of the third Gospel and the Acts of the Apostles, which are attributed to him, appears to support. However, the use of medical terms in these writings may have been commonplace to an educated man of his time. Moreover, it is inferred from Colossians 4:11 that Luke was a Gentile, an inference collaborated by the idiomatic use of Greek in the writings ascribed to him. It does, none the less, show the high importance given to healing in the church from its very inception.

Philo of Alexandria (c. 13 BC-AD 45) mentions physicians in a favourable light, frequently using metaphors which included references to physicians in his allegorical interpretation of events preserved in the Hebrew Scriptures. ${ }^{101}$ Certainly his writings reflect the state of medicine among the Jews of Alexandria. ${ }^{102}$ Josephus (c. 37-100), a Palestinian Pharisee, reflects in his writings the tension to preserve biblical traditions

95 Flavius Josephus, Jewish antiquities, Bk 4: 277 (Josephus, Jewish antiquities, Bks 1-4, vol. 4, transl. H St J Thackeray, Loeb Classical Library, London, W Heinemann; New York, G P Putnam's, 1930, pp. 608-9).

${ }^{96} \mathrm{~b}$ Berakhot $60 \mathrm{a}$; also b Baba Kamma $85 \mathrm{a}$, see note 17 above.

${ }^{97}$ Matt. 9:10-13; Mark 2:15-17; Luke 5:29-32.

${ }^{98}$ In the numerous healing miracles recorded in the Christian Gospels, Jesus is seen as a miracle worker in the tradition of the Hebrew prophets, manifesting by his miracles the work of God, e.g. Matt. 9:2-8; Mark 1:23-28, 3:10-12; Luke 4:33-37, 4:40-1.

${ }^{99}$ Matt. 11:4-5 echoes Isa. 35:4-6 and 61:1; Matt. 8:16-17 describes Jesus's ministry of healing as a fulfilment of the prophecy of Isa. 53: 4 , while Jesus himself is reported as citing his miracles as a sign of his messiahship (John 10: 37-38, cf. Acts 2:22). See G B Ferngren, 'Early Christianity as a religion of healing', Bull. Hist. Med., 1992, 66: 1-15, p. 3.

${ }^{100}$ Matt. 9:20-22; Mark 5:25-34; Luke 8: 43-48.

${ }^{101}$ Cf. Philo, Legum Allegoriae, Bk 3, 61: 177-178 (Philo, vol. 1, transl. G H Whitaker, Loeb Classical Library, London, W Heinemann; New York, G P Putnam's, 1929, pp. 420, 421), part of a commentary on Gen. 48:15-16, in which Philo, in line with Hebrew tradition, ascribes healing to God bestowed by the skill of the physician so allowing the practitioner the credit of healing, though it is God, not the physician who heals.

${ }^{102}$ See Hogan, op. cit., note 36 above, pp. 191-207. 


\section{The Physician in Ancient Israel}

on one hand, and at the same time to render them intelligible to the Hellenized Jew of his own time. ${ }^{103} \mathrm{He}$ is favourably disposed to physicians ${ }^{104}$ but he also makes clear their shortcomings. ${ }^{105}$ The Mishnah acknowledges the physician but does not take a wholly uncritical view as witnessed by the statement that "the best of physicians are fit for Gehenna". ${ }^{106}$ Favourable reference, however, is made to Theudas, a noted physician in Alexandria regarded as an expert on ritual slaughter. ${ }^{107}$ According to the Talmud, the physician had a right to receive a fee for his services since "a physician who works for nothing is worth nothing", and elsewhere in the same tractate $^{108}$ it was required that each physician had a licence from the local court to treat the sick, so implying some form of professional regulation among Jewish physicians. It is in this milieu we find active in Rome, Rufus of Samaria (c. AD 100), the earliest Jewish physician and writer on medicine whose name has survived and who wrote commentaries on the works of Hippocrates. He was well regarded since Galen mentions him in some detail using his medical writings as source material yet also maintaining that, because Rufus was a Jew, he could not appreciate Hippocrates and produce accurate commentaries. ${ }^{109}$

In pre-exilic Israel there was no place for the physician, healing being the exclusive preserve of God. Any attempt to infringe this preserve was regarded as a dereliction of faith in God's power to heal. Physicians first achieved recognition in the postexilic period, although their ability to heal was little regarded. Healing still remained exclusive to God, although magic and folk remedies received divine authorization with an angel acting as an agent of these divinely sanctioned remedies in the account of Tobit. Acknowledgement of the physician began to develop only with the increasing impact of Hellenism on Judaism. It was an acknowledgement that did not achieve ready acceptance and required a syncretism of Jewish magico-folk medicine with Greek practice for the physician to be regarded as the agent of God's healing gifts. The physician's role as the agent of God's healing is well illustrated in a late midrash, ${ }^{110}$ which records how Rabbi Ishmael and Rabbi Akiba when walking in the

\footnotetext{
${ }^{103}$ For example, it is physicians that advise a beautiful virgin be selected to sleep next to the aged King David to keep him warm, but the biblical account (1 Kings. 1:1-4) makes no mention of a physician. See Flavius Josephus, Jewish antiquities, Bk 7:344 (Thackeray and Marcus translation, op. cit., note 59 above, pp. 544-5).

${ }^{104}$ Praising one, Alcyon, who pretended to treat patients so as to remove them from danger that threatened their lives, see Josephus, Jewish antiquities, Bk 19: 157 (Josephus, Jewish antiquities, Bks 18-20, vol. 9, transl. Louis $\mathrm{H}$ Feldman, Loeb Classical Library, London, W Heinemann; Cambridge, MA, Harvard University Press, 1965, pp. 286-7).

${ }^{105}$ Josephus describes how physicians were frequently suppliers of poison to be used against undesirable relatives. See Josephus, The Jewish war, Bk 1: 598 (Thackeray translation, op. cit.,
}

note 23 above, pp. $284-5$ ).

${ }^{106}$ Kiddushin IV. 14, which has been interpreted as a reference to overcharging and over-confidence without regard to God the giver of all healing. See J Jeremias, Jerusalem zur Zeit Jesu: Kulturgeschichtliche Untersuchung zur neutestamentlichen Zeitgeschichte II Teil, Die sozialen Verhältnisse, Göttingen, Eduard Pfeiffer, 1937, p. 177.

${ }^{107}$ Bekhoroth IV: 4. See also S Kottek, 'Alexandrian medicine in the Talmudic corpus', Koroth, 1996-97, 12: 80-90, pp. 85-7.

${ }^{108}$ b Baba Kama 85a.

${ }^{109} \mathrm{R}$ Walzer, Galen on Jews and Christians, London, Oxford University Press, 1949, pp. 9, 17, 80.

${ }^{110}$ See Jellinek, op. cit., note 56 above, pt 1 , vol. 1 , p. 107. 


\section{Nigel Allan}

company of a peasant through the streets of Jerusalem came upon a sick man who asked how he might be healed. Having given him instructions, the rabbis' companion asked who had caused this sickness and the sages replied, "The Holy One blessed be $\mathrm{He}$ ". On receipt of this reply the peasant upbraided the sages for interfering with God's purpose. The rabbis however answered, "As a farmer do you not also do the same? Although God created the earth you have to plough, and till and fertilize and weed if you wish it to yield produce. The body is the tree, the medicine the fertilizer and the physician the tiller of the earth". In this way the physician, regarded as God's agent of healing, came to enjoy an esteemed position in Jewish society down through the centuries to our own time. 